\title{
RELATIONSHIP BETWEEN INDIVIDUALISTIC VALUES AND OPTIMISM: A STUDY OF THE MILLENNIAL GENERATION IN BULGARIA
}

\author{
MARIYA KARAIVANOVA \\ Department of Health Care Management \\ Faculty of Public Health, Medical University-Plovdiv \\ Vassil Aprilov 15A Boulevard, 4002 Plovdiv, Bulgaria \\ E-mail address: mariya.karaivanova@mu-plovdiv.bg \\ ORCID: https://orcid.org/0000-0003-0238-3044
}

\begin{abstract}
Aim. A quantitative study on generational differences showed a decrease in optimism among the young generation (Karaivanova, 2016). The present work aims to study in detail the relationship between individualistic values, self-esteem, and optimism among the Millennial generation. Optimism is a general expectation for positive results and positive events in life (Radoslavova \& Velichkov, 2005).

Method. A sample of 204 respondents from 20 to 35 years old voluntarily filled in a survey containing scales measuring individualistic values, self-esteem, and optimism. The relationship between these variables was tested using regression and mediation analyses. The results were processed using the statistical software SPSS, version 22.0.0.0, and the lavaan application in R Studio.

Results. The theoretical model created and tested in this study proved to have good explanatory power for the dependent variable optimism explaining one-third of its variance and gives significant clarity on the relationship between individualistic values, self-esteem, and optimism for the young generation in Bulgaria.

Conclusion. Individualistic values turned out to predict self-esteem. The more individualistic a person is, the higher they perceive their competences and social image. At the same time, being individualistic, i.e. being open for change and following one's own interests does not make young people look more optimistically towards the future and believe in the solution of every problem they encounter. Individualistic values have a positive mediated effect on optimism with self-esteem as a mediator. Having strong self-confidence makes young people have positive expectations for the future.

Key words: Individualistic values, self-esteem, optimism, young people, Millennial generation
\end{abstract}




\title{
INTRODUCTION
}

\begin{abstract}
A quantitative dissertation study on the differences between two generations demonstrated a decrease in optimism for the contemporary young generation in Bulgaria, the people born between 1980 and 1995, also called the Millennial generation, compared to the older one -the people born before the year 1980 (Karaivanova, 2016). The study findings are unexpected bearing in mind that optimism is typical for young age when all prospects in life, opportunities, and choices are open for the individual (Erikson, 1968). Moreover, in the dissertation study, it was found that also self-esteem is lower among the younger generation comparing to the older one (Karaivanova, 2016). The signs of the successful solution of the psycho-social crises during adolescence and young adulthood are acquiring future prospects, developing a positive attitude towards the self and self-confidence (Erikson, 1968). Obviously, young people tend to have difficulties resolving the psychosocial crises of adolescence and young adulthood in a positive way and developing the above-mentioned virtues. The result is that they have low self-confidence and no feeling towards the future. Further, the dissertation study found that individualistic values are higher among the younger generation compared to the older one. These remarkable findings about the contemporary young generation in Bulgaria raise the question as to whether there is a relationship between individualism, self-esteem, and optimism. The aim of this paper is to create and test a theoretical model on the relationship between these three psychological characteristics, and to try to answer the question what are the predictors of optimism for the future for young people.
\end{abstract}

\section{RELATIONSHIP BETWEEN INDIVIDUALISTIC VALUES, SELF-ESTEEM, AND OPTIMISM}

A growing body of research on the Millennial generation worldwide demonstrates significant differences between generations. The most striking difference is the growing individualism among Millennials (Twenge, 2006) also called "Generation Me" because they are currently the most self-focused generation.

Another noteworthy result of Jean Twenge's (2006) extended research on generations are the findings that anxiety and depression rates have been rising along with individualism although the Millennial generation has grown up in times of relative economic prosperity (Inglehart, 1997; Schwartz, 2005) and free from wars (Twenge, 2006). It has been confirmed by the findings of decreasing optimism levels among young people in Bulgaria. And while in the past, symptoms of depression were more typical for middle aged people, for Generation Me depression occurs during adolescence and young adulthood (Twenge, 2006). A review of the empirical studies on individualistic values among young Bulgarians shows that they have increased significantly in recent years (Papazova \& Garvanova, 2008; Chavdarova, 2008; Mitev \& Kovacheva, 2014). 
If Millennials have grown up in better material prosperity compared to the previous generations and enjoy much more freedom and opportunities, if they are independent and self-reliant, then why are they more anxious and have negative expectations for the future instead of being optimistic?

Twenge (2006) observed a correlation between anxiety which is a precondition for low optimism and the lower social connectedness which is a direct consequence of rising individualism. Optimism is the general disposition to expect positive outcomes and events in life (Scheier \& Carver, 1993; Radoslavova \& Velichkov, 2005) and as such it has a considerable impact on the well-being and the reactions to the stress of the individual (Scheier, Carver, \& Bridges, 1994). Research shows that there is a negative correlation between optimism and stress (Scheier \& Carver, 1987) and a negative correlation between optimism and depression (Seligman, 1995; Radoslavova \& Velichkov, 2005; Karademas, 2006). Obviously, the growing depression rates and the decreasing optimism levels are related. On the other hand, social support was found to predict optimism (Karademas, 2006). According to Twenge (2006) individualistic values have come as a consequence of the falling apart of close communities and the lack of social support in society. Thus, individualistic values and the decreasing optimism levels are also related. The purpose of this paper is to test if individualistic values predict optimism.

\section{SELF-ESTEEM}

Further, it was found that the Millennial generation has higher self-esteem than any generation before them (Glass, 2007; Twenge \& Campbell, 2008) but only on some of the items measuring this construct. The authors of this extended intergenerational research use the two-component model of self-esteem. The self-competence component is based on one's abilities and the individual is viewed as an agent of their actions while the self-liking component is based on one's worth and the individual is viewed as a social object. While the source of self-competence is one's history of success and failure, the sources of self-liking are the appraisals of one's worth given by others (Tafarodi \& Milne, 2002).

Several studies have established a positive association between self-esteem and optimism (Scheier, Carver, \& Bridges, 1994; Heinonen, Räikkönen, \& Keltikangas-Järvinen, 2005). Adolescents with high rates of self-esteem demonstrated significantly lower levels of pessimism in adulthood compared to those with low self-esteem in adolescence (Heinonen, Räikkönen, \& Keltikangas-Järvinen, 2005). According to Michael Scheier and Charles Carver (1993) one of the sources of the expected outcomes are the evaluations of the self. Optimism/pessimism is partly learned from past experiences of success and failure and at the same time experiences of success and failure cause individual differences in self-esteem. 
The research on intergenerational differences showed that self-liking increases while self-competence decreases (Twenge \& Campbell, 2008). If selfesteem predicts optimism (Heinonen, Räikkönen, \& Keltikangas-Järvinen, 2005), the decreasing self-competence levels could explain the decreasing optimism. If people perceive themselves as not competent enough, their feelings of helplessness grow. On the other hand, mastering challenges and experiencing individual achievement, i.e. being competent is the source of optimism (Seligman, 1995). This paper aims to test how self-competence predicts optimism.

\section{INDIVIDUALISTIC VALUES}

Values construct guiding principles in people's lives that vary in importance (Schwartz, 2005). They are divided into two large groups - individualistic and collectivist interests based on whether they serve mainly one's own needs and interests or the interests of others and the community (Schwartz, 1992).

Individualistic values are positively related to self-esteem (Feather, 1991; Lönnqvist et al., 2009). As already mentioned, several studies among student samples in Bulgaria identify the same strong tendency towards individualisation in our society over the last few years (Papazova \& Garvanova, 2008; Chavdarova, 2008; Mitev \& Kovacheva, 2014) accompanied by decreasing self-esteem and optimism. These results are expected, bearing in mind that self-esteem is positively associated with optimism (Heinonen, Räikkönen, \&

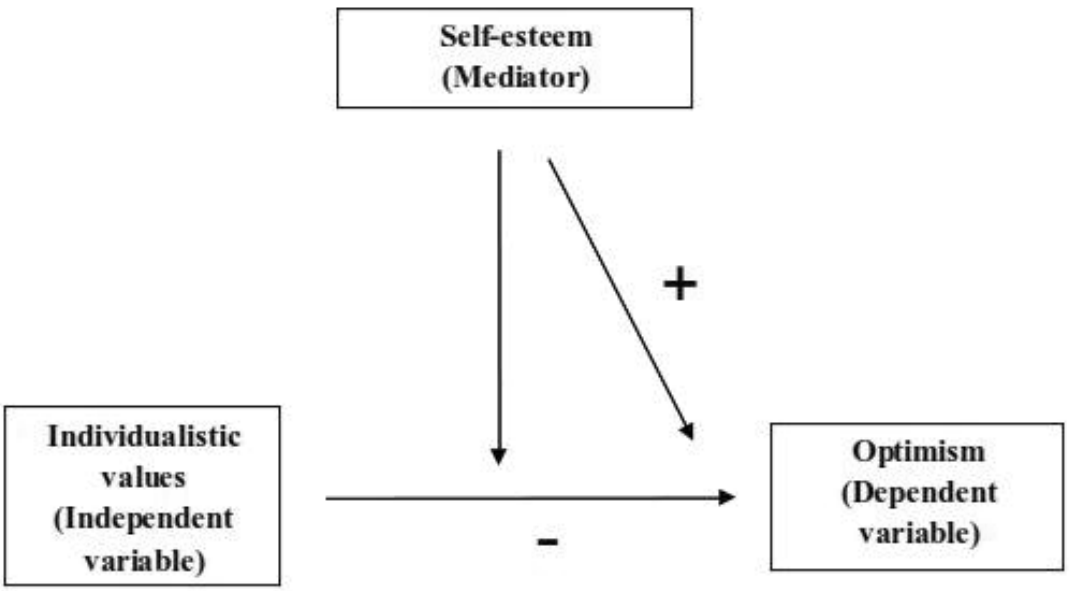

Fig. 1. Theoretical model of the relationship between individualistic values (IV), self-esteem (M) and optimism (DV)

Note: IV - Independent variable; M - Mediator; DV - Dependent variable

Source: own research. 
Keltikangas-Järvinen, 2005) but raises the question of what the role of selfesteem on the relationship between individualistic values and optimism is? This study aims to test the mediating role of self-esteem on the relationship between individualistic values and optimism.

Based on the literature review, the relationship between the three variables is hypothesized and illustrated in the model presented in Figure 1. The arrows in the figure represent the hypothesized correlations between the variables that will be tested during the statistical analyses. Based on previous findings, it is hypothesized that individualistic values predict optimism in a negative way, i.e. the more individualistic a person is, the less optimistic for the future they are, and that self-esteem has a mediating effect on this relationship.

\section{METHOD AND MEASURES}

Method:

The respondents filled in a questionnaire consisting of the following scales: Personal values, Optimism and two scales measuring self-competence, and selfliking plus demographic questions. All items were in the form of statements and the respondents had to agree on a 5-point Likert-type scale ranging from 1 $=$ "I completely disagree" to $5=$ "I completely agree." The items in the different scales are not arranged in sequence in the questionnaire but mixed up. The study was conducted anonymously, voluntarily, and without payment to the respondents. The first group of respondents was surveyed on paper, the rest of the respondents were approached on the Internet and asked to fill in the questionnaire. All of them were informed that the survey was conducted for the purpose of scientific dissertation research. They were also instructed to be honest and objective in their responses regarding their personal values, attitudes and preferences. The average time for filling in the questionnaire was 20-25 minutes. The survey was conducted between May and September 2015. The survey was filled in by 204 respondents in total.

\section{Measures:}

Individualistic values: One of the most widely used models in psychology to describe values on both individual level and cultural level is the model offered by Shalom Schwartz (1992).

For the present study, we use the version adapted for the Bulgarian population by Krassimira Baychinska (1994). The respondent is presented with a list of values and asked to rate them from 1 to 7 starting with the most important ones (marking them with 7) and then continuing with the values opposing to him/her (marking them with -1) and the least important ones (marking them with 0). Examples are the values: exciting life, varying life and daring which form the stimulation value type for the Bulgarian population. For the purposes of data analysis, the scale is regarded as Likert-type and interval. In this study we use only the Individualism subscale of the Schwartz Values 
Survey. It consists of 20 items and demonstrates good internal reliability Cronbach's Alpha coefficient is 0.85 .

Optimism. The instrument used in the current study has been developed by Angel Velichkov and Maria Radoslavova (2005) and standardised for the Bulgarian population. The scale consists of 10 items and its Cronbach's Alpha coefficient is high -0.85 . Respondents are instructed to describe their attitude to things that happen in life by rating all 10 statements on a Likerttype scale ranging from $1=$ "I completely disagree" to $5=$ "I completely agree." Example items from the Optimism scale are "I am convinced that bad things don't last long" and "When I think about the past, I usually remember the good things."

Table 1

Factor analysis of the Self-esteem scale

\begin{tabular}{lccc}
\hline Item & Factor 1 & Factor 2 & Factor 3 \\
\hline Self-liking 2 & .438 & & \\
Self-liking 6 & .338 & & \\
Self-competence 2 & .414 & .577 & .687 \\
Self-competence 4 & & & \\
Self-liking 5 & & .582 & \\
Self-competence 6 & & & \\
Self-liking 3 & .426 & .386 & .551 \\
Self-competence 8 & & .679 & .498 \\
Self-competence 3 & & & \\
Self-liking 1 & .668 & & .431 \\
Self-competence 5 & & & $5.99 \%$ \\
Self-liking 8 & .521 & & .70 \\
Self-liking 7 & .415 & .70 & \\
Self-competence 7 & .530 & & \\
Self-competence 1 & & & \\
Self-liking 4 & \% & & \\
\% explained variance & $25.2 \%$ & & \\
a-Cronbach & & & \\
\hline
\end{tabular}

Source: own research.

Self-esteem: To measure self-esteem, Romin Tafarodi and William Swann's (2001) concept for the two components of global self-esteem is used. The instrument they offer consists of two subscales - self-competence and self-liking - and it is based on their earlier research work distinguishing between selfevaluations based on personal competence (observable abilities and skills) on one hand, and appearance, character and social identity (attractiveness, social worth) on the other. Example items for the self-competence subscale include: "I am highly effective at the things I do" (positive) and "I sometimes 
deal poorly with challenges"(negative). Example items for the self-liking subscale are: "I am secure in my sense of self-worth" (positive) and "I have a negative attitude toward myself" (negative). As the scale is used for the first time for the Bulgarian population, an exploratory factor analysis (using principal axis analysis and varimax rotation) was conducted to check if the items load on the same two factors. The exploratory factor analysis demonstrated a factor structure with three factors with eigenvalues greater than 1 . The positively-worded items of the self-competence and self-liking subscales loaded around one factor with factor loadings ranging from 0.41 to 0.67 . This factor consists of 8 items. The second factor unites the 4 negatively-worded items from the self-competence subscale with factor loadings ranging from 0.39 to 0.68 . The final factor unites the 4 negatively-worded items from the self-liking subscale. The factor loadings range from 0.43 to 0.69 . The correlations between the three factors are moderate to high ranging from 0.39 to 0.45 . The total percentage of variance explained by the three factors is $37.5 \%$. To measure self-esteem in this study, we will use the subscale with the 8 positively worded items in order to check the mediating effect of self-esteem on the relationship between individualistic values and optimism. This subscale has been chosen for two reasons. Obviously, for the Bulgarain population self-esteem consists of one component including items from both subscales - the one based on one's history of success and failure, and the other based on the appraisals of one's worth given by others. So, this subscale was chosen as a mediator between the independent and the dependent variable in the further statistical analysis because it includes both aspects of the studied concept. The other two factors were excluded from further analysis because they include either only items measuring self-esteem based on one's abilites, or only items measuring self-esteem based on one's worth. Thus, the other two factors do not comprise the integrity of the concept. Another reason to exclude them was that they have lower reliability coefficient than the first factor (Cronbach's Alpha coefficient equals 0.70 for the second and third factor). The scale included in further analysis has Cronbach's Alpha coefficient of 0.78 .

Table 2

Descriptive statistics of the scales

\begin{tabular}{lcccc}
\hline \multicolumn{1}{c}{ Scale } & Number of items & a-Cronbach & $\begin{array}{c}\text { Scale mean } \\
(\mathrm{N}=204)\end{array}$ & SD (N=204) \\
\hline Individualistic values & 20 & 0.85 & 80.35 & 16.97 \\
Self-esteem & 8 & 0.78 & 24.89 & 4.19 \\
Optimism & 10 & 0.85 & 38.21 & 6.36 \\
\hline
\end{tabular}

Source: own research.

\section{Sample:}

Our sample consists of 204 respondents from 20 to 35 years old who voluntarily filled in the survey both on paper and online. 114 of the respondents 
filled in the questionnaire on paper and the rest (90) - online. In this study, a convenience sample consisting mainly of university students is used. 53 of them are males and 150 - females. 81 of the respondents have secondary education, and 122 - a higher education degree. 147 of them study full-time or part-time, and only 55 have finished studies. 45 are currently unemployed and - 157 are employed full-time or part-time. The results were processed using the statistical software SPSS, version 22.0.0.0 and the lavaan application in R Studio.

\section{RESULTS}

Relationship between individualistic values, self-esteem and optimism. Correlations

In order to check the empirical distribution of the data, a KolmogorovSmirnov Z test was conducted. The Optimism scale has a K-S Z test score of .087, Sig. =.003, the Individualistic values scale has a K-S Z test score of .061, Sig.=.200 and the Self-esteem scale has a K-S Z test score of .069 , Sig. $=.045$. The Optimism scale scores are statistically significant different from a normal distribution $(p<0.01)$, for the other two scales it can be accepted that they are normally distributed. Therefore, we can assume that the data is normally distributed and apply parametric statistical tests to the data.

In order to check the relationship between the three constructs, Pearson correlation analyses were performed.

Table 3

Relationship between individualistic values, self-esteem and optimism.

\begin{tabular}{lccc}
\hline & Self-esteem & Individualistic values & Optimism \\
\hline Self-esteem & 1 & $.256^{* *}$ & $.521^{* *}$ \\
Individualistic values & $.256^{* *}$ & 1 & $.165^{*}$ \\
Optimism & $.521^{* *}$ & $.165^{*}$ & 1 \\
\hline
\end{tabular}

Note: $\mathrm{r}=$ Pearson correlation; $\mathrm{n}=204$

${ }^{*}$ Correlation is significant at the $p<0.05$ level

${ }^{* *}$ Correlation is significant at the $\mathrm{p}<0.01$ level

Source: own research.

As seen from the table, optimism is strongly positively correlated to selfesteem and moderately positively correlated to individualistic values. The higher self-esteem people have and the more individualistic they are, the more optimism they have for the future. The correlation between individualistic values and self-esteem is also moderate - more strongly expressed individualistic values are related to higher self-esteem. As a next step, we will see how each of the two constructs - individualistic values and self-esteem - predict optimism using regression analyses.

Predictors of optimism. Regression analysis 
Regression analyses were performed as they give a clearer picture of the specific factors that influence the dependent variable in the model. The performed regression analyses eliminate the multicollinearity of the independent variables. Thus, only predictors that have a significant impact on the studied constructs and this impact is independent of the variance of the other variables remain. The results are presented in the tables below.

Table 4

Regression analysis. Model summary

\begin{tabular}{ccccc}
\hline Model & $\mathrm{R}$ & $\mathrm{R}$ Square & Adjusted R Square & Std. error of estimate \\
\hline 1 & .567 & .321 & .313 & 5.23 \\
\hline Source: own research & & &
\end{tabular}

Source: own research.

The model has good predictability explaining $31 \%$ of the variance in optimism (Adjusted R Square $=.313$ ).

Table 5

Predictors of Optimism. Coefficients

\begin{tabular}{|c|c|c|c|c|c|}
\hline Model & $\begin{array}{c}\text { Unstandardised } \\
\text { coefficients }\end{array}$ & & $\begin{array}{c}\text { Standardised } \\
\text { coefficients }\end{array}$ & & \\
\hline & $\mathrm{B}$ & Std. error & Beta & $\mathrm{T}$ & Sig. \\
\hline 1 (Constant) & 15.835 & 2.874 & & 5.510 & .000 \\
\hline $\begin{array}{l}\text { Individualistic } \\
\text { values }\end{array}$ & -.005 & .025 & -.013 & -.199 & .843 \\
\hline Self-esteem & .908 & .106 & .570 & 8.576 & .000 \\
\hline
\end{tabular}

Source: own research.

Self-esteem is a statistically significant predictor of optimism (Beta $=.908$, Sig. $=.000$ at $p<0.001$ ). When young people have higher self-esteem, feel competent and appreciated by others, this makes them expect more positive things to happen in the future. Individualistic values predict optimism negatively but are not a statistically significant predictor (Beta $=-.005$, Sig. $=.843$ ). In summary, higher self-esteem is related to higher optimism but individualistic values are not.

\section{Mediation analysis}

In order to explore the relationship between the three constructs more fully and to test if self-esteem mediates the relationship between individualistic values and optimism, mediation analysis was performed using the lavaan package in R Studio. The results are presented in the figure and tables below. 


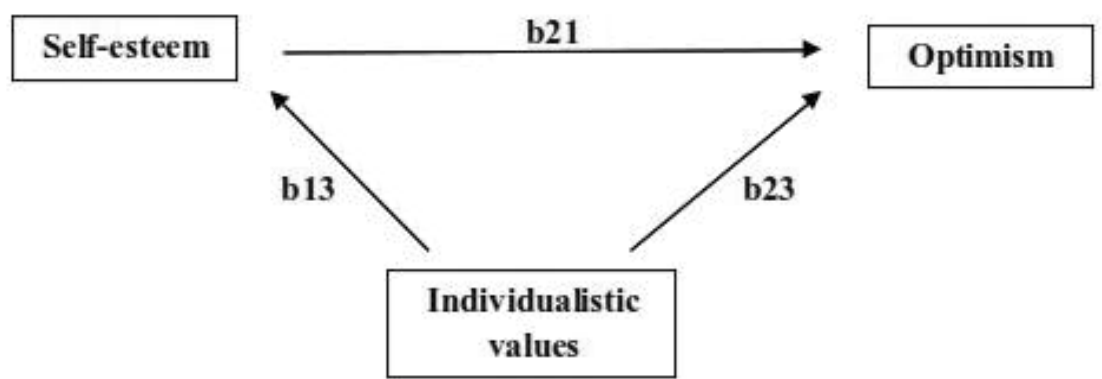

Fig. 2. Mediation. Direct and indirect effects

Note: b23 - direct effect; b13*b21 - indirect effect; b23 + b13*b21 - total effect

Source: own research.

The suggested mediation model was tested using the lavaan package in R Studio. In the table below, the results from the mediation analysis are presented.

Table 6

Relationship between individualistic values, self-esteem and optimism. Mediation analysis

\begin{tabular}{|c|c|c|c|c|c|c|}
\hline Effect & $\begin{array}{l}\text { Unstandardised } \\
\text { coefficient - Est }\end{array}$ & $\begin{array}{l}\text { Std. } \\
\text { error }\end{array}$ & $\begin{array}{l}\text { Standardised } \\
\text { coefficient - z }\end{array}$ & $\begin{array}{l}\mathrm{p} \\
\text { value }\end{array}$ & $\begin{array}{l}\text { CI } \\
\text { lower }\end{array}$ & $\begin{array}{l}\text { CI } \\
\text { upper }\end{array}$ \\
\hline $\begin{array}{l}\text { Optimism } \\
\text { Self-esteem } \\
\text { b21 }\end{array}$ & .908 & .114 & 7.990 & .000 & .687 & 1.128 \\
\hline $\begin{array}{l}\text { Optimism } \\
\text { Individualistic } \\
\text { values b23 }\end{array}$ & -.005 & .022 & -.229 & .819 & -.051 & .036 \\
\hline $\begin{array}{l}\text { Self-esteem } \sim \\
\text { Individualistic } \\
\text { values b13 }\end{array}$ & .064 & .020 & 3.197 & .001 & .026 & .106 \\
\hline $\begin{array}{l}\mathrm{b} 21 * \mathrm{~b} 13 \\
\text { (indirect) }\end{array}$ & .058 & .020 & 2.916 & .004 & .022 & .103 \\
\hline $\begin{array}{l}\text { indirect }+\mathrm{b} 23 \\
\text { (total) }\end{array}$ & .053 & .026 & 2.012 & .044 & .001 & .106 \\
\hline
\end{tabular}

Note: bootstrap $=1000$

Source: own research.

As we have already seen, self-esteem predicts optimism positively $($ Est $=$ .908 , Sig. $=.000$ ). The same is not valid for individualistic values - the result did not reach statistical significance (Est $=-.005$, Sig.=.819). However, individualistic values predict self-esteem positively (Est $=.064$, Sig. $=.001$ ). 


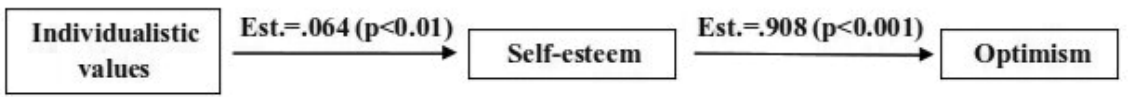

Fig. 3. Results of the mediation analysis with coefficients

Source: own research.

The indirect effect of individualistic values and self-esteem predicts positively optimism (Est $=.058$, Sig.=.004). This means that individualistic values have a positive mediated effect on optimism with self-esteem as a mediator. The total effect also reaches statistical significance (Est=.053, Sig.=.044). But we do not have a direct effect of individualistic values on optimism which suggests full mediation. The model explains $32 \%$ of the variance in optimism and $7.4 \%$ of the variance in self-esteem.

\section{DISCUSSION}

The self-competence/self-liking scale was used for the first time on a Bulgarian sample of respondents for measuring self-esteem. It differentiates between self-esteem based on skills and abilities, and self-esteem based on social worth or the appreciation by others. The scale was analysed using the exploratory factor analysis technique. The exploratory factor analysis demonstrated that in Bulgaria the scale does not have a two-factor but a three-factor structure uniting the positively-worded items measuring one's perceived competences and one's perceived social worth in one factor. This factor reflecting one's positive self-perception was used in the theoretical model in the present study.

The theoretical model created and tested in this study proved to have good explanatory power for the dependent variable optimism explaining one-third of its variance and gives significant clarity on the relationship between individualistic values, self-esteem, and optimism for the young generation in Bulgaria. It significantly contributes to our better understanding of the concept of optimism.

\section{CONCLUSION}

Individualistic values turned out to predict self-esteem as measured by the above-mentioned scale. The more individualistic a person is, the higher they perceive their competences and social image. Enhancing their own interests and being open to change and novelty puts young people in many situations in which they perceive themselves as competent, effective and feel content with themselves. Facing challenges helps them build strong self-confidence and have a positive attitude towards themselves.

At the same time, being individualistic, i.e. being open to change and following one's own interests does not make young people look more optimis- 
tically towards the future and believe in the solution to every problem they encounter. Following one's own interests and independent thoughts are not enough for expecting good things to happen in the future - the key is selfesteem, i.e. being confident in one's personal qualities and talents. Having strong self-confidence makes young people have positive expectations for the future. Individualistic values have a positive mediated effect on optimism with self-esteem as a mediator. Having in mind that self-esteem explains a large percentage of the variance in optimism (Adjusted R square $=.27$ ), the low selfesteem levels could be an explanation for the decreasing optimism among young people. Further research should focus on the predictors of both selfesteem and optimism for the Millennial generation in Bulgaria.

\section{REFERENCES}

[1] Baychinska, K. (1994). Tsennosti. Tsennosten stres... Tsennostna kriza! [Values, value stress... Value crisis]. Sofia: Academic press "Marin Drinov".

[2] Chavdarova, V. (2008). Tsennostni naglasi pri sotsialni promeni (sravnitelno prouchvane mezhdu bulgarski i ukrainski studenti) [Value attitudes in times of social change (a comparative study between Bulgarian and Ukrainian students)]. Psychological Research, 2, 87-97.

[3] Erikson, E. H. (1968). Identity, youth and crisis. New York: W. W. Norton Company.

[4] Feather, N. T. (1991). Human values, global self-esteem, and belief in a just world. Journal of Personality, 59(1), 83-107.

[5] Glass, A. (2007). Understanding generational differences for competitive success. Industrial and Commercial Training, 39(2), 98-103.

[6] Heinonen, K., Räikkönen, K., \& Keltikangas-Järvinen, L. (2005). Self-esteem in early and late adolescence predicts dispositional optimism-pessimism in adulthood: a 21-year longitudinal study. Personality and Individual Differences, 39, 511-521.

[7] Inglehart, R. (1997). Modernization and post-modernization: Cultural, economic and political change in 43 societies. Princeton: Princeton University Press.

[8] Karademas, E. C. (2006). Self-efficacy, social support and well-being. The mediating role of optimism. Personality and Individual Differences, 40, 1281-1290.

[9] Karaivanova, M. (2016). Values, self-evaluations and future expectations of the Millennial generation (Doctoral dissertation). Sofia: St. Kliment Ohridski University.

[10] Lönnqvist, J. E., Verkasalo, M., Helkama, K., Andreyeva, G. M., Bezmenova, I., Manganelli Rattazzi, A. M., Niit, T., \& Stetsenko, A. (2009). Self-esteem and values. European Journal of Social Psychology, 39, 40-51.

[11] Mitev, P, E., Kovacheva, S. (2014). Mladite khora v evropeyska Bulgariya: sotsiologicheski portret 2014 [Young people in European Bulgaria: a sociological portrait 2014]. Sofia: Friedrich Ebert Foundation.

[12] Papazova, E., Garvanova, M. (2008). Osnovni individualni tsennosti pri bulgarski studenti - sravnitelen analiz [Basic individual values in Bulgarian students - a comparative study]. Psychological Research, 2, 7-16.

[13] Radoslavova, M., \& Velichkov, A. (2005). Metodi za psihodiagnostika [Methods for psychodiagnostics]. Sofia: Pandora Prim.

[14] Scheier, M. F., Carver, C. S. (1987). Dispositional optimism and psychological well-being: The influence of generalized outcome expectations on health. Journal of Personality, 55, 169-210.

[15] Scheier, M. F., Carver, C. S. (1993). On the power of positive thinking: The benefits of being optimistic. Current Directions in Psychological Science, 2, 26-30.

[16] Scheier, M. F., Carver, C. S., \& Bridges, M. W. (1994). Distinguishing optimism from neuroticism (and trait anxiety, self-mastery, and self-esteem): A reevaluation of the life orientation test. Journal of Personality and Social Psychology, 67, 1063-1078.

[17] Schwartz, S. H. (1992). Universals in the content and structure of values: theoretical advances 
and empirical tests in 20 countries. In: M. Zanna (Ed.), Advances in experimental social psychology, vol. 25 (pp. 1-65). Orlando: Academic Press.

[18] Schwartz, S. H. (2005). Basic human values: Their content and structure across countries. In: A. Tamayo, \& J. B. Porto (Eds.), Valores e comportamento nas organizações [Values and behavior in organizations] (pp. 21-55). Petrópolis, Brazil: Vozes.

[19] Seligman, M. E. P. (1995). The optimistic child: How learned optimism protects children from depression. Boston: Houghton Mifflin.

[20] Tafarodi, R. W., Swann, W. B. (2001). Two-dimensional self-esteem: theory and measurement. Personality and Individual Differences, 31(5), 653-673.

[21] Tafarodi, R. W., Milne, A. B. (2002). Decomposing global self-esteem. Journal of Personality, $70,443-483$.

[22] Twenge, J. M. (2006). Generation me: Why today's young Americans are more confident, assertive, entitled and more miserable than ever before. New York: Free Press.

[23] Twenge, J. M., Campbell, W. K. (2008). Increases in positive self-views among high school students: birth-cohort changes in anticipated performance, self-satisfaction, self-liking, selfcompetence. Psychological Science, 19, 1082-1086. 